\title{
Antioxidant, Antibacterial, Cytotoxic, and Anti-Inflammatory Potential of the Leaves of Solanum lycocarpum A. St. Hil. (Solanaceae)
}

\author{
Guilherme Augusto Ferreira da Costa, Melissa Grazielle Morais, \\ Aline Aparecida Saldanha, Izabela Caputo Assis Silva, Álan Alex Aleixo, \\ Jaqueline Maria Siqueira Ferreira, Adriana Cristina Soares, \\ Joaquim Maurício Duarte-Almeida, and Luciana Alves Rodrigues dos Santos Lima
}

Universidade Federal de São João Del-Rei, Campus Centro-Oeste Dona Lindu, 35501-296 Divinópolis, MG, Brazil

Correspondence should be addressed to Luciana Alves Rodrigues dos Santos Lima; luarsantos@ufsj.edu.br

Received 18 March 2015; Accepted 20 April 2015

Academic Editor: Daniela Rigano

Copyright (c) 2015 Guilherme Augusto Ferreira da Costa et al. This is an open access article distributed under the Creative Commons Attribution License, which permits unrestricted use, distribution, and reproduction in any medium, provided the original work is properly cited.

\begin{abstract}
Ethanol extract and fractions obtained from leaves of Solanum lycocarpum were examined in order to determine their phenolic composition, antioxidant, antibacterial, anti-inflammatory, and cytotoxic potential. High performance liquid chromatography coupled with DAD analysis indicated that the flavonoids apigenin and kaempferol were the main phenolic compounds present in dichloromethane and ethyl acetate fractions, respectively. The antioxidant activity was significantly more pronounced for dichloromethane, ethyl acetate, and hydroethanol fractions than that of the commercial antioxidant 2,6-di-tert-butyl-4methylphenol. The hexane and dichloromethane fractions were more active against the tested bacteria. The hydroethanol fraction exhibited significant anti-inflammatory activity at the dose of 75 and $150 \mathrm{mg} / \mathrm{kg}$ in the later phase of inflammation. However, the antiedematogenic effect of the higher dose of the ethyl acetate fraction $(150 \mathrm{mg} / \mathrm{kg})$ was more pronounced. The ethyl acetate fraction also presented a less cytotoxic effect than the ethanol extract and other fractions. These activities found in S. lycocarpum leaves can be attributed, at least in part, to the presence of phenolic constituents such as flavonoids. This work provided the knowledge of phenolic composition in the extract and fractions and the antioxidant, antibacterial, anti-inflammatory, and cytotoxic activities of leaves of S. lycocarpum.
\end{abstract}

\section{Introduction}

Polyphenolic compounds, such as flavonoids and phenolic acids, are commonly consumed as natural components of vegetables, beans, fruits, and/or phytotherapeutics and are generally regarded as safe chemicals, thus displaying low toxicological activity [1]. These compounds have been presented as therapeutic alternatives for the treatment of a large number of pathologies [2]. Flavonoids, particularly apigenin and luteolin, have shown potent activity against oxidative stress [3]. Other studies in several systems have revealed that apigenin was able to inhibit tumor growth [4]. Additionally, recent studies have shown anti-inflammatory, antimicrobial, and antioxidant properties for kaempferol and kaempferol rhamnosides [5, 6]. Cinnamic acids, such as caffeic and chlorogenic acids, are also very well known for their antioxidant properties $[7,8]$.

The Solanaceae family comprises about 3000 species and 150 genera. It is prevalent in tropical and subtropical regions of South America and has economic importance because several species of the Solanum genus are cultivated for food, such as Solanum tuberosum (potato), Solanum lycopersicum (tomato), Solanum melongena (eggplant), and Solanum gilo (gilo) [9]. The species Solanum lycocarpum A. St. Hil., popularly known as the "fruit of the wolf," is widely distributed in the Brazilian Cerrado. The fruits are usually consumed "in natura" or used in jellies, jams, or pasta preparations [10]. It is widely used in traditional medicine as a sedative, in the 
treatment of epilepsy, asthma, diabetes, obesity, the reduction of cholesterol levels, and abdominal and renal pains [11]. Biological activities such as anti-inflammatory, antioxidant, cytotoxic, antibacterial, allelopathic, and larvicidal have been reported for this species $[10,12-14]$.

Phytochemical studies of this species showed that solasonine and solamargine are two predominant steroidal glycoalkaloids, which have a common aglycone, solasodine [15]. A recent study also reported the presence of cinnamic acids, such as caffeic and chlorogenic acids, in ripe fruits of $S$. lycocarpum [13]. However, until now, no data exist about the phenolic composition of the leaves of S. lycocarpum and their antioxidant, antibacterial, anti-inflammatory, and cytotoxic activities. The aim of this study was to identify the main phenolic compounds and estimate the total flavonoid content of the ethanol extract (EE) and fractions obtained from the leaves of $S$. lycocarpum and also to demonstrate their antioxidant, antibacterial, anti-inflammatory, and cytotoxic potential.

\section{Materials and Methods}

2.1. Chemicals. Ascorbic acid (AA), 2,6-di-tert-butyl-4methylphenol (BHT), 1,1-diphenyl-2-picrylhydrazyl (DPPH), kaempferol, quercetin, rutin, apigenin, luteolin, coumaric acid, 3-(4,5-dimethylthiazol-2-yl)-2,5-diphenyltetrazolium bromide (MTT), carrageenan $\lambda$ type IV, indomethacin, HPLC grade methanol, and acetonitrile were obtained from Sigma (St. Louis, MO, USA). Caffeic, ferulic, and chlorogenic acids were purchased from Apin Chemicals Ltd. (Abingdon, $\mathrm{UK})$. Mueller Hinton broth $(\mathrm{MH})$ medium was acquired from Himedia (Mumbai, India). Streptomycin, penicillin, and fetal bovine serum (FBS) were purchased from Cultilab (Campinas, SP, Brazil). Dulbecco's Modified Eagle's Medium (DMEM) was purchased from Gibco (Grand Island, NY, USA). All other reagents were of analytical grade and were obtained from Vetec (Duque de Caxias, RJ, Brazil).

2.2. Plant Material and Extraction. The leaves of S. lycocarpum A. St. Hil. were collected in São Sebastião do Oeste, Minas Gerais, Brazil, in August 2011. The plant material was identified by Dr. Alexandre Salino and a voucher specimen (BHCB 159397) was deposited at the Instituto de Ciências Biológicas Herbarium, Universidade Federal de Minas Gerais, Belo Horizonte, MG, Brazil. As S. lycocarpum a Brazilian native genetic material, the present study had been approved by the Conselho Nacional de Desenvolvimento Científico e Tecnológico (CNPq) through Access and Shipment Component of Genetic Heritage for scientific research purpose (number 010655/2011-5).

Extraction of the dried and powdered leaves $(121.00 \mathrm{~g})$ by percolation (EtOH, $7 \mathrm{~L}, 72 \mathrm{~h}$ ) gave the $\mathrm{EE}$ (17.02 g). Part of this extract (7.90 g) was dissolved in EtOH/ $\mathrm{H}_{2} \mathrm{O}(1: 1)$ and successively extracted with $\mathrm{C}_{6} \mathrm{H}_{14}, \mathrm{CH}_{2} \mathrm{Cl}_{2}$, and EtOAc, resulting in $1.90,0.48,0.67$, and $3.20 \mathrm{~g}$ of hexane (Hex), dichloromethane (DCM), ethyl acetate (Ac), and hydroethanol (HE) fractions.

2.3. Total Flavonoid Content. The total flavonoid contents were estimated according to the Dowd method [16], with modifications. Exactly $2 \mathrm{~mL}$ of $2 \%$ aluminum trichloride $\left(\mathrm{AlCl}_{3}\right)$ in methanol was mixed with the same volume of the extract or fraction solution $(1.0 \mathrm{mg} / \mathrm{mL})$. The absorbance was read at $415 \mathrm{~nm}$ using a Hitachi 2010 spectrophotometer after $10 \mathrm{~min}$, with a blank sample consisting of a $2 \mathrm{~mL}$ extract or fraction solution with $2 \mathrm{~mL}$ methanol without $\mathrm{AlCl}_{3}$. Rutin was used as the reference compound to produce the standard curve, and total flavonoid contents were expressed as $\mu \mathrm{g}$ of rutin equivalents/mg of extract or fraction. All assays were performed in triplicate.

2.4. Phenolic Profiles by HPLC-DAD. The phenolic substances in the ethanol extract and fractions were carried out using analytical reversed phase HPLC on an Agilent 1260 system with an autosampler and quaternary pump coupled with a diode array detector. Compound separation was performed by a Zorbax Eclipse Plus 5B RP-18 (5 $\mu \mathrm{m}, 250$ $\times 4.6 \mathrm{~mm}$, Agilent, USA) column. The mobile phases were (A) water/formic acid (99.9:0.1) and (B) acetonitrile. The gradient consisted of $20 \%$ of (B) for 2 minutes and increased to $30 \%$ of (B) after 10 minutes, $50 \%$ of (B) after another 10 minutes, and $70 \%$ of (B) after an additional 10 minutes. For column cleaning, 90\% of phase (B) was used [7]. Each sample was injected in duplicate, ranging from 5 to $20 \mu \mathrm{L}$ according to the sample concentration. Determination was performed by comparing the retention times and the UV spectra against those obtained from the standards (apigenin, kaempferol, luteolin, quercetin, rutin, caffeic, coumaric, ferulic, and chlorogenic acids). The determination was positive when the similarity between the chromatograms was equal to or greater than $90 \%$.

2.5. DPPH Radical Scavenging Assay. The radical scavenging abilities of extract and fractions of $S$. lycocarpum were based on reactions with 1,1-diphenyl-2-picrylhydrazyl radical (DPPH) and compared to standards, 2,6-di-tert-butyl-4methylphenol (BHT) and ascorbic acid (AA). Determination of antioxidant activity by the DPPH method was adapted for use with microplates [17]. Briefly, a solution of DPPH $(0.002 \% \mathrm{w} / \mathrm{v})$ was prepared in $80 \%$ methanol. Volumes of $75 \mu \mathrm{L}$ of samples or standards $(1,10,100,250$, and $500 \mu \mathrm{g} / \mathrm{mL})$ were added to wells in a 96-well flat-bottom plate containing $150 \mu \mathrm{L}$ of DPPH solution. The plate was then covered and left in the dark at room temperature $\left(25^{\circ} \mathrm{C}\right)$. After $30 \mathrm{~min}$, absorbance at $517 \mathrm{~nm}$ was measured in a spectrophotometer (Biotek Power Wave XS2/US), and 80\% methanol was used for the baseline correction. Scavenging ability was expressed as the inhibition percentage and was calculated by the following equation [18]:

$$
\begin{aligned}
& \text { Scavenging ability }(\%) \\
& =\frac{\left(\mathrm{Abs}_{\text {control }}-\mathrm{Abs}_{\text {sample }}\right)}{A b s_{\text {control }}} \times 100,
\end{aligned}
$$

where $\mathrm{Abs}_{\text {control }}=$ absorbance of $\mathrm{DPPH}$ radical in $80 \%$ methanol and $\mathrm{Abs}_{\text {sample }}=$ absorbance of samples and standards in $80 \%$ methanol + DPPH. The antioxidant activity of all samples was expressed as $\mathrm{IC}_{50}$, which was defined as 
the concentration (in $\mu \mathrm{g} / \mathrm{mL}$ ) of samples required to inhibit the formation of DPPH radicals by $50 \%$ IC $_{50}$ values were calculated by Probit analysis [19]. All assays were performed in triplicate.

2.6. Determination of Cytotoxicity by the MTT Assay. The cytotoxic potential of the extract and fractions was evaluated using the MTT assay [20]. LLC-MK2 (Rhesus monkey kidney) cells were maintained at $37^{\circ} \mathrm{C}$, under $5 \% \mathrm{CO}_{2}$, in DMEM supplemented with $5 \%$ FBS, $50 \mathrm{U} / \mathrm{mL}$ penicillin, and $50 \mu \mathrm{g} / \mathrm{mL}$ streptomycin in a 96 -well microplate, until they reach $95 \%$ confluence. After $72 \mathrm{~h}$ exposure to dosages from 400 to $3.125 \mu \mathrm{g} / \mathrm{mL}, 20 \mu \mathrm{L}(2 \mathrm{mg} / \mathrm{mL})$ of phosphate buffered saline (PBS) was added to each well and the plate was incubated at $37^{\circ} \mathrm{C}$ for $3 \mathrm{~h}$. The medium was removed and $130 \mu \mathrm{L}$ DMSO was added. After incubation at $37^{\circ} \mathrm{C}$ for $10 \mathrm{~min}$, the absorbance at $540 \mathrm{~nm}$ was measured in a spectrophotometer (Biotek Power Wave XS2, USA) to determine the concentration that killed $50 \%$ of the cells $\left(\mathrm{CC}_{50}\right)$. The cytotoxicity was calculated after comparing with the control (treated with 0.1\% DMSO).

2.7. Culture and Maintenance of the Bacterial Isolates. Eight bacterial strains, which included Gram-positive Bacillus cereus ATCC 11778, Enterococcus faecalis ATCC 19433, Listeria monocytogenes ATCC 15315, Staphylococcus aureus ATCC 29213, and Streptococcus mutans ATCC25175 and Gramnegative Escherichia coli EHEC ATCC 43895, Klebsiella pneumoniae ATCC 27736, and Pseudomonas aeruginosa ATCC 25853 , were used in the biological assays. All bacterial strains were stored at $-80^{\circ} \mathrm{C}$.

Suspensions from the cultures of the bacteria were prepared in accordance with the guidelines in the CLSI M7-A7 document [21] to obtain a final suitable inoculum of $1.5 \times$ $10^{6} \mathrm{UFC} / \mathrm{mL}$.

\subsection{Determination of the Minimal Inhibitory Concentration.} The minimal inhibitory concentration (MIC) values were obtained by broth microdilution testing performed in accordance with the guidelines in the CLSI M7-A7 document [21], with modifications. Streptomycin and penicillin were included as positive control. The stock solution was prepared in water. $\mathrm{MH}$ medium without samples or solvents was used as a control for growth and sterility.

The EE and fractions were dissolved in sterile 20\% dimethylsulfoxide (DMSO). Later, serial dilutions were made with $\mathrm{MH}$, maintaining a constant volume of $1000 \mu \mathrm{L}$ in each tube. In this way, the samples were tested at eight concentrations that varied from 15.62 to $2000 \mu \mathrm{g} / \mathrm{mL}$ and the concentrations of the positive control varied from 7.81 to $1000 \mu \mathrm{g} / \mathrm{mL}$. An inoculum of $125 \mu \mathrm{L}$ of cell culture was added to $25 \mu \mathrm{L}$ of each concentration of samples in $\mathrm{MH}$ in 96 -well plates. DMSO at $2 \%(\mathrm{v} / \mathrm{v})$ was used as a control for toxicity.

After inoculation of bacteria, the plates were incubated at $37^{\circ} \mathrm{C}$ for $24 \mathrm{~h}$. The MIC values were expressed in $\mu \mathrm{g} / \mathrm{mL}$ and correspond to the lowest concentrations that inhibited $80 \%$ of bacterial growth, by measuring the absorbance at $540 \mathrm{~nm}$ (Biotek Power Wave XS2, USA). All assays were performed in triplicate and repeated at least once.
2.9. Determination of Minimal Bactericidal Concentration. The minimum bactericidal concentration (MBC) of the EE and fractions was determined by streaking $25 \mu \mathrm{L}$ from each well that showed inhibition of $80 \%$ of bacterial growth onto an agar plate and counting by a Pour-Plate Method [22]. After incubation at $37^{\circ} \mathrm{C}$ for $24 \mathrm{~h}$, colonies were counted. The MBC was determined as the lowest sample concentration at which less than $0.1 \%$ of the initial inoculum $\left(1.5 \times 10^{6} \mathrm{UFC} / \mathrm{mL}\right)$ was able to grow. All assays were performed in triplicate and repeated at least once.

2.10. Evaluation of the In Vivo Anti-Inflammatory Activity. Carrageenan induces paw edema biphasically: the initial phase ( 0 to $2.5 \mathrm{~h}$ ) is characterized by the release of histamine, serotonin, and bradykinins, and the later phase begins due to the overproduction of prostaglandins such as $\mathrm{PGE}_{2}$ in paw [23].

The volume of the Swiss mice paws was measured with a plethysmometer (Insight, Brazil), according to a method reported previously [24]. The basal volume of the left hind paw was determined before the administration of any drugs. Vehicle (DMSO 5\% in saline, $10 \mathrm{~mL} / \mathrm{kg}$, control group), ethanol extract, hexane, dichloromethane, ethyl acetate, and hydroethanol fractions (all at doses 75 and $150 \mathrm{mg} / \mathrm{kg}$ ) or indomethacin $10 \mathrm{mg} / \mathrm{kg}$ ( $n=6$ per group) was intraperitoneally administered 30 minutes before the intraplantar (i.pl.) injection of carrageenan $(400 \mu \mathrm{g} / \mathrm{paw}, 30 \mu \mathrm{L})$. The paw volume was measured $1,2,4$, and $6 \mathrm{~h}$ after the injection of the inflammatory stimulus. The difference between the paw edema after and before (basal volume) carrageenan injection was taken as the volume of edema and was determined for each mouse. The percentage of edema inhibition in treated animals was calculated in comparison to the control group (vehicle).

This experiment was in agreement with the Ethical Principles in Animal Experimentation adopted by the Ethics Committee in Animal Experimentation of Universidade Federal de São João Del Rei, Brazil (CEUA/UFSJ) (Protocol 028/2013).

2.11. Statistical Analysis. Student's $t$-test was utilized to evaluate the statistical difference between the control group and the group exposed to the EE and fractions of S. lycocarpum. Data of paw edema are presented as means \pm standard error of the mean (S.E.M.) of measurements. For statistical analysis, the data were analyzed by a one-way analysis of variance (ANOVA), followed by the Bonferroni's post hoc test for multiple comparisons. A $p$ value 0.05 was considered statistically significant. The analyses were performed using the GraphPad Prism 5.0 software (San Diego, CA, USA).

\section{Results and Discussion}

3.1. Antioxidant Activity, Total Flavonoids Content, and HPLC Analysis. The scavenging effects on the DPPH radical of the ethanol extract and fractions obtained from the leaves of $S$. lycocarpum and $\mathrm{IC}_{50}$ values are shown in Table 1. Ethanol extract, fractions, and positive controls (ascorbic acid (AA) and 2,6-di-tert-butyl-4-methylphenol (BHT)) were capable 
TABLE 1: DPPH-scavenging activity, $\mathrm{IC}_{50}$ values, total flavonoids, and cytotoxic activity of ethanol extract and fractions from leaves of Solanum lycocarpum.

\begin{tabular}{|c|c|c|c|c|c|c|c|c|}
\hline \multirow{2}{*}{ Samples } & \multicolumn{5}{|c|}{ DPPH scavenging activity } & \multirow{2}{*}{$\mathrm{IC}_{50}(\mu \mathrm{g} / \mathrm{mL})$} & \multirow{2}{*}{ TFC } & \multirow{2}{*}{$\begin{array}{c}\mathrm{CC}_{50}(95 \% \mathrm{CL}) \\
\mu \mathrm{g} / \mathrm{mL}\end{array}$} \\
\hline & $1 \mu \mathrm{g} / \mathrm{mL}$ & $10 \mu \mathrm{g} / \mathrm{mL}$ & $100 \mu \mathrm{g} / \mathrm{mL}$ & $250 \mu \mathrm{g} / \mathrm{mL}$ & $500 \mu \mathrm{g} / \mathrm{mL}$ & & & \\
\hline $\mathrm{EE}$ & $32.03 \pm 0.42^{\mathrm{ab}}$ & $37.16 \pm 0.34^{\mathrm{ab}}$ & $93.69 \pm 0.23^{\mathrm{ab}}$ & $97.42 \pm 0.06^{\mathrm{ab}}$ & $99.38 \pm 0.27^{\mathrm{a}}$ & $36.63 \pm 6.06^{\mathrm{ab}}$ & $8.40 \pm 0.74$ & $10.20 \pm 1.54$ \\
\hline Hex & $38.66 \pm 0.52^{\mathrm{a}}$ & $41.82 \pm 0.64^{\mathrm{ab}}$ & $47.29 \pm 0.58^{\mathrm{ab}}$ & $58.28 \pm 0.91^{\mathrm{ab}}$ & $67.02 \pm 0.69^{\mathrm{ab}}$ & $178.14 \pm 33.63^{\mathrm{ab}}$ & $3.40 \pm 0.47$ & $13.51 \pm 3.72$ \\
\hline DCM & $33.34 \pm 0.24^{\mathrm{ab}}$ & $66.00 \pm 0.17^{\mathrm{ab}}$ & $71.37 \pm 0.62^{\mathrm{ab}}$ & $83.56 \pm 0.83^{\mathrm{ab}}$ & $99.59 \pm 0.19^{\mathrm{a}}$ & $4.29 \pm 0.89^{\mathrm{ab}}$ & $168.00 \pm 2.89$ & $165.70 \pm 4.00$ \\
\hline Ac & $43.48 \pm 0.29^{\mathrm{ab}}$ & $65.73 \pm 0.73^{\mathrm{ab}}$ & $76.65 \pm 0.29^{\mathrm{ab}}$ & $92.43 \pm 0.28^{\mathrm{ab}}$ & $97.10 \pm 0.69^{\mathrm{ab}}$ & $1.82 \pm 0.32^{\mathrm{a}}$ & $184.00 \pm 1.73$ & $9975.00 \pm 5.41$ \\
\hline $\mathrm{HE}$ & $32.09 \pm 1.67^{\mathrm{ab}}$ & $65.88 \pm 0.84^{\mathrm{ab}}$ & $87.80 \pm 0.35^{\mathrm{ab}}$ & $91.91 \pm 0.40^{\mathrm{b}}$ & $98.41 \pm 0.05^{\mathrm{ab}}$ & $3.46 \pm 0.45^{\mathrm{ab}}$ & $105.00 \pm 1.15$ & $25.00 \pm 2.01$ \\
\hline BHT & $18.50 \pm 0.24$ & $25.90 \pm 0.64$ & $86.00 \pm 0.56$ & $91.40 \pm 0.28$ & $94.02 \pm 0.64$ & $16.36 \pm 1.63$ & - & - \\
\hline AA & $39.10 \pm 0.34$ & $82.60 \pm 0.26$ & $90.80 \pm 0.32$ & $95.08 \pm 0.43$ & $99.80 \pm 0.58$ & $1.62 \pm 0.25$ & - & - \\
\hline
\end{tabular}

Ethanol extract (EE), hexane (Hex), dichloromethane (DCM), ethyl acetate (Ac), and hydroethanol (HE) fractions, 2,6-di-tert-butyl-4-methylphenol (BHT) and ascorbic acid (AA).

$\mathrm{IC}_{50}$ : concentration (in $\mu \mathrm{g} / \mathrm{mL}$ ) of samples required to inhibit the formation of DPPH radicals by $50 \%$.

TFC: total flavonoids content: results expressed as $\mu \mathrm{g}$ of rutin equivalents/mg of extract or fraction.

$\mathrm{CC}_{50}$ : concentration that killed $50 \%$ of cells; CL: confidence limits.

Each value in the table is the mean \pm standard deviation $(n=3) .{ }^{\mathrm{a}} p<0.05$ compared with $\mathrm{BHT},{ }^{\mathrm{b}} p<0.05$ compared with AA.

of scavenging DPPH radicals in a concentration-dependent manner. The samples exhibited activities greater than the positive control BHT, at concentrations of 1 and $10 \mu \mathrm{g} / \mathrm{mL}$. As can be seen from the $\mathrm{IC}_{50}$ values (Table 1), dichloromethane (DCM), ethyl acetate (Ac), and hydroethanol (HE) fractions were the most potent antioxidants, with an $\mathrm{IC}_{50}$ of $4.29,1.82$, and $3.46 \mu \mathrm{g} / \mathrm{mL}$, respectively, having an activity better than BHT, a commercial antioxidant $\left(\mathrm{IC}_{50}=16.36 \mu \mathrm{g} / \mathrm{mL}\right)$. The ethanol extract (EE) and hexane fraction (Hex) showed low antioxidant potential, with high $\mathrm{IC}_{50}$ values. The Ac fraction can be considered the best antioxidant among all of the extracts under investigation. The $\mathrm{EE}$ and fractions were less active than $\mathrm{AA}$, with an $\mathrm{IC}_{50}$ of $1.62 \mu \mathrm{g} / \mathrm{mL}$.

The $\mathrm{IC}_{50}$ values found for the EE and fractions of $S$. lycocarpum on the DPPH radical were statistically significant when compared with BHT and AA. The $p$ value for comparison of the EE and fractions of $S$. lycocarpum with BHT was 0.001 . The $p$ value for the comparison of the EE and fractions of S. lycocarpum with AA was 0.001, except for the Ac fraction, with a $p$ value $>0.05$.

In a previous study on the ripe fruits of S. lycocarpum, the ethanol extracts and fractions exhibited antioxidant activity by the $\mathrm{DPPH}$ method, with $\mathrm{IC}_{50}$ values estimated to be between 2.96 and $172.00 \mu \mathrm{g} / \mathrm{mL}$ [13]. The dichloromethane, ethyl acetate, and hydroethanol fractions from leaves of $S$. lycocarpum presented lower $\mathrm{IC}_{50}$ values than the similar fractions of ripe fruits of $S$. lycocarpum, exhibiting a greater antioxidant activity.

The dichloromethane, ethyl acetate, and hydroethanol fractions had the highest total flavonoid content: 168.00, 184.00 , and $105.00 \mu \mathrm{g}$ equivalents to rutin $/ \mathrm{mg}$ of fraction, respectively. The total flavonoids contents of ethanol extract and hexane fraction were estimated to be 8.40 and $3.40 \mu \mathrm{g}$ equivalents to rutin/mg of extract or fraction, respectively (Table 1). Phenolic compounds, such as flavonoids, have very strong antioxidant activity and are much more effective than vitamins $\mathrm{C}$ and $\mathrm{E}$ in protecting cells from free radical damage $[25,26]$.
The chromatograms of HPLC-DAD of samples of leaves of S. lycocarpum revealed the presence of flavonoids. Flavone and flavonol (apigenin and kaempferol) were detected in the dichloromethane and ethyl acetate fractions, respectively (Figure 1). No phenolic compounds were detected in the ethanol extract and hexane and hydroethanol fractions. In the DCM fraction chromatogram, some peaks could be noted. In this chromatogram, a peak (observed between 7.0 and $7.1 \mathrm{~min}$ ) had similar spectrum with apigenin $(264,298 \mathrm{sh}, 311 \mathrm{~nm})$. In the chromatogram obtained with the $\mathrm{AC}$ fraction, a spectrum similar to kaempferol derivative $(264,301 \mathrm{sh}, 356 \mathrm{~nm})$ was observed at $6.0 \mathrm{~min}$, as the second most pronounced peak (Figure 1). The flavonoids apigenin and kaempferol have been identified in other species of the genus Solanum, such as $S$. crinitum and S. nigrum [27, 28]. The flavonoids are plant natural compounds and an integral part of the human diet, with increasing evidence that dietary polyphenols are likely candidates for the observed beneficial effects of a diet rich in fruits and vegetables for the prevention of several chronic diseases [29].

3.2. Cytotoxic Activity. The cytotoxicity of the EE and fractions from leaves of $S$. lycocarpum was evaluated in the LLCMK2 cell line by the MTT colorimetric assay. The results showed that the Ac fraction presented less of a cytotoxic effect than the EE and other fractions, with $\mathrm{CC}_{50}=9975 \mu \mathrm{g} / \mathrm{mL}$ (Table 1). The DCM fraction showed little cytotoxic activity, with $\mathrm{CC}_{50}$ value of $165.70 \mu \mathrm{g} / \mathrm{mL}$. The EE and Hex and HE fractions showed highest cytotoxicity, with $\mathrm{CC}_{50}$ values of $10.20,13.51$, and $25.00 \mu \mathrm{g} / \mathrm{mL}$, respectively.

In a previous study on the ripe fruits of S. lycocarpum, the ethanol extracts and fractions were evaluated in the LLCMK2 cell line by the MTT assay. The results showed that the Hex fraction presented less of a cytotoxic effect, the EE and HE fraction showed moderated cytotoxicity, and the DCM and Ac fractions showed little cytotoxic activity [13]. Glycoalkaloids from the fruits of S. lycocarpum were also evaluated for cytotoxic activity, using LLC-MK2 cells. The 

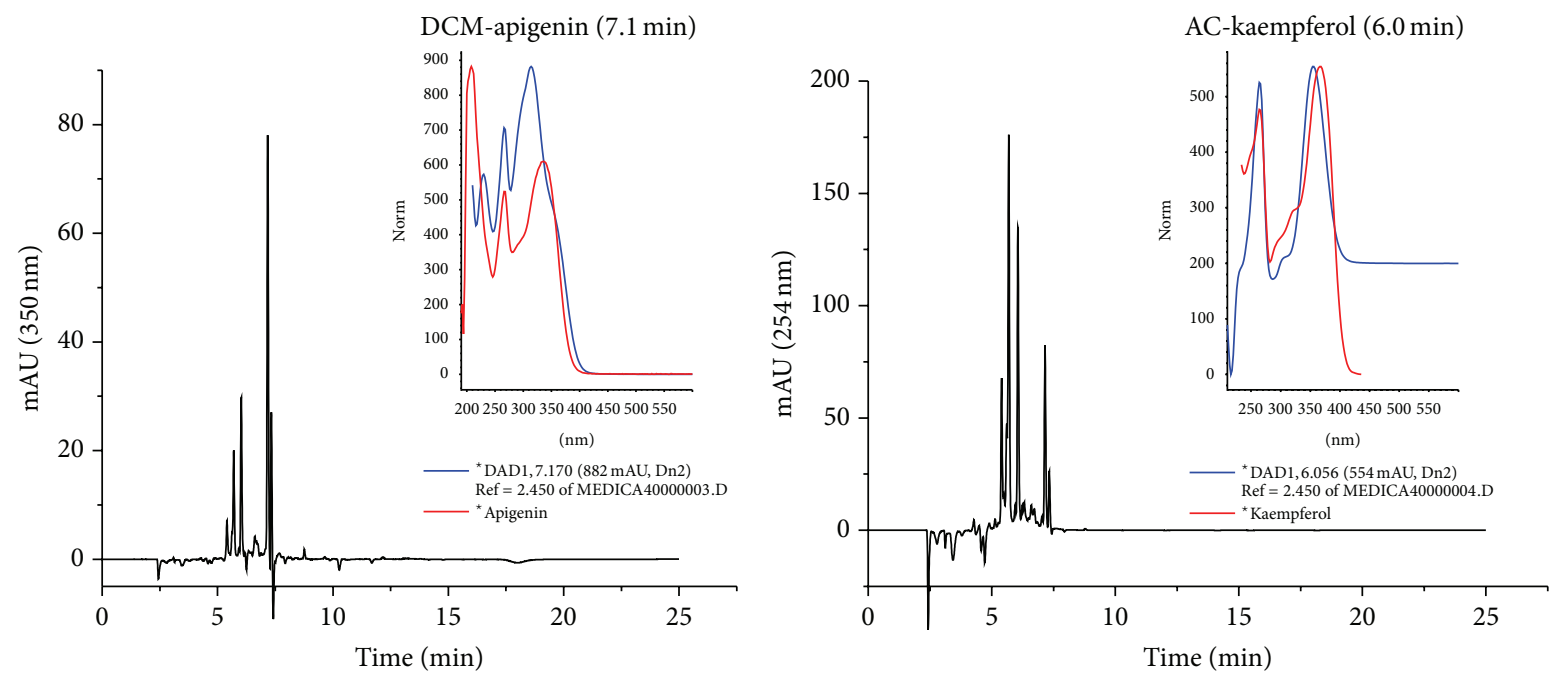

FIGURE 1: HPLC chromatograms of extract and fractions from Solanum lycocarpum by elution with water acidified with chromic acid $(0.1 \% \mathrm{v} / \mathrm{v})$ and acetonitrile, monitored at 350 and $254 \mathrm{~nm}$; dichloromethane fraction (DCM) and ethyl acetate fraction (Ac). Major peaks (DCM) apigenin and (AC) kaempferol derivatives.

results revealed that the samples were effectively nontoxic to the cells [15], corroborating results in this study for the DCM and Ac fractions.

3.3. Antibacterial Activities. The antibacterial activities of the EE and fractions from leaves of S. lycocarpum were evaluated against eight bacterial strains of clinical interest (Table 2). The fractions presented good antibacterial activity against the Gram-positive bacteria L. monocytogenes, with MIC values in the range of $500-2000 \mu \mathrm{g} / \mathrm{mL}$. The HE fraction was more active against $L$. monocytogenes, with an MIC value of $500 \mu \mathrm{g} / \mathrm{mL}$. The DCM and HE fractions were also active against $B$. cereus, with an MIC value of $1000 \mu \mathrm{g} / \mathrm{mL}$. These results are interesting, because both of these bacteria are food-borne pathogens responsible for gastrointestinal infections with high morbidity [30]. B. cereus is a food-poisoning pathogen frequently diagnosed as the causative agent of gastroenteritis, but it may also cause more severe diseases, such as endophthalmitis and meningitis [30, 31].

The Hex fraction was also active against $S$. aureus, $S$. mutans, and E. coli, with MIC values of 2000, 1000, and $1000 \mu \mathrm{g} / \mathrm{mL}$, respectively. The DCM fraction showed good activity against $S$. aureus and $K$. pneumoniae, with an MIC of $2000 \mu \mathrm{g} / \mathrm{mL}$. The Ac fraction was active against $P$. aeruginosa $(\mathrm{MIC}=2000 \mu \mathrm{g} / \mathrm{mL})$. Conversely, the EE extract was active against bacteria tested.

The MBC of the fractions are shown in Table 2. The DCM and HE fractions showed bactericidal activity against L. monocytogenes, with MBC values of 2000 and $1000 \mu \mathrm{g} / \mathrm{mL}$, respectively. The DCM fraction against $L$. monocytogenes showed an $\mathrm{MBC}$ result that was equivalent to the MIC result. It can be concluded that this sample exhibited bactericidal and bacteriostatic effects at the same concentration. The MIC and $\mathrm{MBC}$ values found for the EE and fractions of S. lycocarpum were statistically significant when compared with streptomycin and penicillin, with a $p$ value of 0.0001 .
The Solanaceae family has revealed its potential as antimicrobial agents. Solanum species have also been described as possessing antibacterial properties against strains of medical importance [13, 32-34]. The ethanol extract and fractions from the ripe fruits of $S$. lycocarpum present activity against B. cereus, E. faecalis, L. monocytogenes, S. aureus, S. mutans, $S$. pyogenes, and $K$. pneumonia, with MIC values in the range of $31-2000 \mu \mathrm{g} / \mathrm{mL}$ [13]. Acetone and methanol extracts of Solanum nigrum leaves exhibited activity against $B$. cereus, S. epidermidis, S. aureus, Micrococcus kristinae, and P. aeruginosa, with an MIC of $5 \mathrm{mg} / \mathrm{mL}$ [33]. S. tuberosum showed the highest activity against $S$. aureus and E. faecalis, with MIC values of $15.6-31.3 \mu \mathrm{g} / \mathrm{mL}$ [34]. Extracts of the fruits of Solanum incanum and $S$. nigrum were shown to be active against $S$. aureus, B. subtilis, E. coli, P. aeruginosa, and Micrococcus flavus, with MIC values in the range of 500-1000 $\mu \mathrm{g} /$ $\mathrm{mL}[32]$.

3.4. In Vivo Anti-Inflammatory Activity. The anti-inflammatory activity of the EE and fractions from leaves of $S$. lycocarpum was evaluated by paw edema-induced carrageenan. The ethanol extract, hexane, and dichloromethane fractions did not inhibit paw edema (data not shown).

Both applied doses of HE fraction (75 and $150 \mathrm{mg} / \mathrm{kg}$ ) and $150 \mathrm{mg} / \mathrm{kg}$ of Ac fraction from S. lycocarpum leaves exerted a significant anti-inflammatory action in the mice paw edema test (Figure 2). The suppression of local edema formation by the higher dose of $\mathrm{HE}$ and Ac fractions was $60 \%$ and $80 \%$, respectively, $4 \mathrm{~h}$ after injection of carrageenan and $67 \%$ and $75 \%$, respectively, $6 \mathrm{~h}$ after the inflammatory stimulus. The inhibition of edema observed was pronounced in the later phase of inflammation, which was similar to the effect of nonsteroidal anti-inflammatory drugs such as indomethacin [35], indicating that the antiedematogenic activity is possibly mediated through a cyclooxygenase enzyme inhibitory pathway [36]. 
TABLE 2: Minimal inhibitory concentration (MIC) and minimal bactericidal concentration (MBC) of ethanol extract and fractions from leaves of Solanum lycocarpum against eight bacteria of clinical interest.

\begin{tabular}{|c|c|c|c|c|c|c|c|c|c|c|c|c|}
\hline \multirow{3}{*}{ Bacteria } & \multicolumn{12}{|c|}{ Concentration $(\mu \mathrm{g} / \mathrm{mL})$} \\
\hline & \multicolumn{2}{|c|}{$\mathrm{EE}$} & \multicolumn{2}{|c|}{ Hex } & \multicolumn{2}{|c|}{$\mathrm{DCM}$} & \multicolumn{2}{|c|}{ Ac } & \multicolumn{2}{|c|}{$\mathrm{HE}$} & \multicolumn{2}{|c|}{ Streptomycin/penicillin } \\
\hline & MIC & $\mathrm{MBC}$ & MIC & $\mathrm{MBC}$ & MIC & $\mathrm{MBC}$ & MIC & $\mathrm{MBC}$ & MIC & $\mathrm{MBC}$ & MIC & MBC \\
\hline Bacillus cereus & $>2000$ & - & $>2000$ & - & $1000^{*}$ & $>2000$ & $>2000$ & - & $1000^{*}$ & $>2000$ & 7 & 1000 \\
\hline Enterococcus faecalis & $>2000$ & - & $>2000$ & - & $>2000$ & - & $>2000$ & - & $>2000$ & - & 1000 & 1000 \\
\hline Listeria monocytogenes & $>2000$ & - & $2000^{*}$ & $>2000$ & $2000^{*}$ & $2000^{*}$ & $>2000$ & - & $500^{*}$ & 1000 & 125 & 125 \\
\hline Staphylococcus aureus & $>2000$ & - & $2000^{*}$ & $>2000$ & $2000^{*}$ & $>2000$ & $>2000$ & - & $>2000$ & - & 7 & 125 \\
\hline Streptococcus mutans & $>2000$ & - & $1000^{*}$ & $>2000$ & $>2000$ & $>2000$ & $>2000$ & - & $>2000$ & - & 7 & 7 \\
\hline Escherichia coli & $>2000$ & - & $1000^{*}$ & $>2000$ & $>2000$ & - & $>2000$ & - & $>2000$ & - & 15 & 30 \\
\hline Klebsiella pneumoniae & $>2000$ & - & $>2000$ & - & $2000^{*}$ & $>2000$ & $>2000$ & - & $>2000$ & - & 15 & 15 \\
\hline Pseudomonas aeruginosa & $>2000$ & - & $>2000$ & - & $>2000$ & - & $2000^{*}$ & $>2000$ & $>2000$ & - & 62 & 125 \\
\hline
\end{tabular}

Ethanol extract (EE), hexane (Hex), dichloromethane (DCM), ethyl acetate (Ac), and hydroethanol (HE) fractions.

${ }^{*} p<0.05$ compared with streptomycin/penicillin.

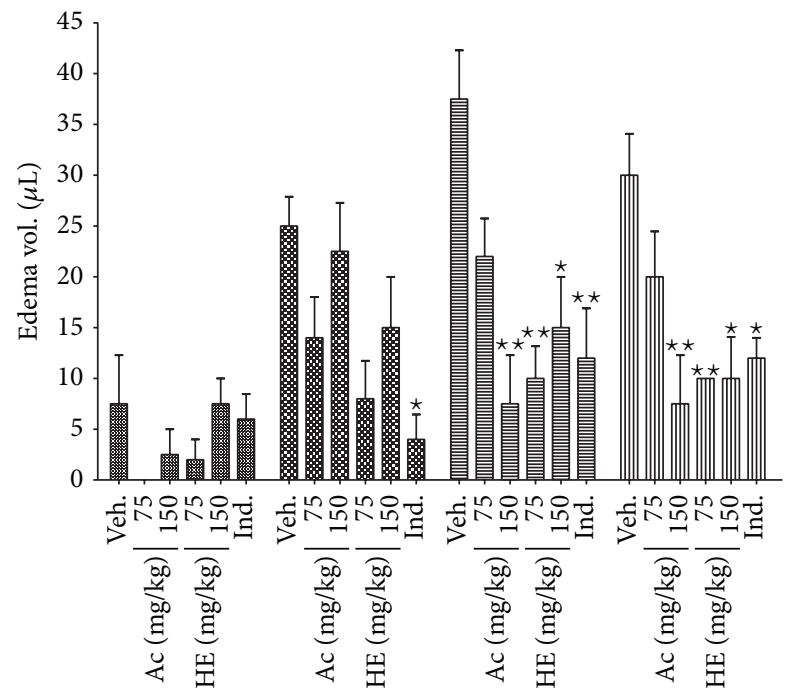

$1 \mathrm{~h}$ after carrageenan injection $\ominus 4 \mathrm{~h}$ after carrageenan injection ॠ $2 \mathrm{~h}$ after carrageenan injection $\mathrm{m} 6 \mathrm{~h}$ after carrageenan injection

FIGURE 2: Anti-inflammatory effect of hydroethanol (HE) and ethyl acetate (Ac) fractions from S. lycocarpum versus time after inflammatory stimulus on carrageenan-induced paw edema. Paw edema was measured with plethysmometer; results expressed as paw edema in $\mu \mathrm{L}$ (mean \pm SEM); treatments: HE and Ac fractions from S. lycocarpum (75 and $150 \mathrm{mg} / \mathrm{kg}$ ), vehicle (Veh. 5\% DMSO), or indomethacin (Ind. $10 \mathrm{mg} / \mathrm{kg}$ ) thirty minutes before intraplantar carrageenan injection $(400 \mu \mathrm{g} / \mathrm{paw}) . n=6$ animals/group. ANOVA, Bonferroni's Multiple Comparison Test; ${ }^{*} p<0.05$ and ${ }^{* *} p<0.01$ in comparison to control group (vehicle).

The ethyl acetate fraction had better anti-inflammatory and antioxidant activities and the highest total flavonoid content. Phenolic compounds such as flavonoids possess antiinflammatory activity, which is related to their antioxidant activity [37]. The inflammatory process is a complex response and reactive oxygen species play an important role in the pathogenesis of inflammatory diseases [38]. One of the antiinflammatory mechanisms of phenols seems to be related to the inhibition of NF- $\kappa \mathrm{B}$ transcription and the reduction of the expression of several target genes that are indispensable to the inflammatory process [39-41]. Kaempferol, identified as the constituent of the Ac fraction (Figure 1), could account for the antiedematogenic effect. A previous study demonstrated that the anti-inflammatory property of kaempferol is related to the inhibitory effect on nitric oxide (NO) production and NF- $\kappa \mathrm{B}$ mediated luciferase activity [5].

\section{Conclusion}

The DCM, Ac, and HE fractions were the most potent antioxidants, with an activity that was better than BHT, and also have the highest total flavonoid content. In the DCM and Ac fractions, the flavonoids (apigenin and kaempferol, resp.) were detected. The Hex and DCM fractions were more active than the EE and other fractions against the tested bacteria. In addition, we confirm the anti-inflammatory activity of $\mathrm{HE}$ (75 and $150 \mathrm{mg} / \mathrm{kg}$ ) and Ac (150 mg/kg) fractions from S. lycocarpum leaves. The Ac fraction also presented a less cytotoxic effect than the EE and other fractions. These activities found in $S$. lycocarpum leaves can be attributed, at least partially, to the presence of phenolic constituents such as flavonoids. These results encourage additional studies to evaluate the possibilities of using the extract and fractions of leaves of S. lycocarpum as a potential source of natural antioxidant, antibacterial, and anti-inflammatory compounds in complementary and alternative therapeutics.

\section{Conflict of Interests}

The authors do not have any conflict of interests.

\section{Acknowledgments}

The authors thank the Campus Centro-Oeste Dona Lindu of Universidade Federal de São João Del-Rei (CCO/UFSJ) for the infrastructure. The authors are grateful to the Universidade Federal de São João Del-Rei (UFSJ), Conselho Nacional de Desenvolvimento Científico e Tecnológico 
(CNPq), Coordenação de Aperfeiçoamento de Pessoal de Nível Superior (CAPES), and Fundação de Amparo a Pesquisa do Estado de Minas Gerais (FAPEMIG) for their fellowships, to Laboratory for Reference Materials of the Oswaldo Cruz Foundation, FIOCRUZ, by the donation of bacteria strains, and to Professor Dr. Alexandre Salino for botanical identification of this plant. They are grateful to Centro de Pesquisa René Rachou of the Oswaldo Cruz Foundation (CPqRR/FIOCRUZ) and Universidade Federal de São João Del-Rei (UFSJ) by the donation of Swiss mice.

\section{References}

[1] P. C. H. Hollman and M. B. Katan, "Health effects and bioavailability of dietary flavonols," Free Radical Research, vol. 31, supplement, pp. S75-S80, 1999.

[2] B. A. Graf, P. E. Milbury, and J. B. Blumberg, "Flavonols, flavones, flavanones, and human health: epidemiological evidence," Journal of Medicinal Food, vol. 8, no. 3, pp. 281-290, 2005.

[3] S. E. Nielsen, J. F. Young, B. Daneshvar et al., "Effect of parsley (Petroselinum crispum) intake on urinary apigenin excretion, blood antioxidant enzymes and biomarkers for oxidative stress in human subjects," British Journal of Nutrition, vol. 81, no. 6, pp. 447-455, 1999.

[4] P. V. S. Jeyabal, M. B. Syed, M. Venkataraman, J. K. Sambandham, and D. Sakthisekaran, "Apigenin inhibits oxidative stressinduced macromolecular damage in N-nitrosodiethylamine (NDEA)-induced hepatocellular carcinogenesis in Wistar albino rats," Molecular Carcinogenesis, vol. 44, no. 1, pp. 11-20, 2005.

[5] H. S. Rho, A. K. Ghimeray, D. S. Yoo et al., "Kaempferol and kaempferol rhamnosides with depigmenting and anti-inflammatory properties," Molecules, vol. 16, no. 4, pp. 3338-3344, 2011.

[6] S. J. N. Tatsimo, J. D. D. Tamokou, L. Havyarimana et al., "Antimicrobial and antioxidant activity of kaempferol rhamnoside derivatives from Bryophyllum pinnatum," BMC Research Notes, vol. 5, article 158, 2012.

[7] J. M. Duarte-Almeida, A. Salatino, M. I. Genovese, and F. M. Lajolo, "Phenolic composition and antioxidant activity of culms and sugarcane (Saccharum officinarum L.) products," Food Chemistry, vol. 125, no. 2, pp. 660-664, 2011.

[8] Y. Sato, S. Itagaki, T. Kurokawa et al., "In vitro and in vivo antioxidant properties of chlorogenic acid and caffeic acid," International Journal of Pharmaceutics, vol. 403, no. 1-2, pp. 136138, 2011.

[9] V. C. Souza and H. Lorenzi, Botânica Sistemática-Guia Ilustrado para Identificação das Famílias de Angiospermas da Flora Brasileira, Baseado em APG II, Instituto Plantarum, Nova Odessa, Brazil, 2008.

[10] G. Vieira Jr., P. M. Ferreira, L. G. Matos et al., "Anti-inflammatory effect of Solanum lycocarpum fruits," Phytotherapy Research, vol. 17, no. 8, pp. 892-896, 2003.

[11] C. C. Munari, P. F. de Oliveira, I. M. de Souza Lima et al., "Evaluation of cytotoxic, genotoxic and antigenotoxic potential of Solanum lycocarpum fruits glicoalkaloid extract in V79 cells," Food and Chemical Toxicology, vol. 50, no. 10, pp. 3696-3701, 2012.

[12] M. G. Morais, V. C. B. Silva, G. T. Oliveira, J. M. S. Ferreira, and L. A. R. S. Lima, "Allelopathic potential of the ripe fruits of Solanum lycocarpum A. St. Hil. (Solanaceae)," Biochemistry and Biotechnology Reports, vol. 2, no. 4, pp. 37-41, 2013.

[13] M. G. Morais, G. A. F. da Costa, Á. A. Aleixo et al., "Antioxidant, antibacterial and cytotoxic potential of the ripe fruits of Solanum lycocarpum A. St. Hil. (Solanaceae)," Natural Product Research, vol. 29, no. 5, pp. 480-483, 2015.

[14] T. M. Pereira, V. C. B. Silva, J. A. Ribeiro Neto, S. N. Alves, and L. A. R. S. Lima, "Larvicidal activity of the methanol extract and fractions of the green fruits of Solanum lycocarpum (Solanaceae) against the vector Culex quinquefasciatus (Diptera: Culicidae)," Revista da Sociedade Brasileira de Medicina Tropical, vol. 47, no. 5, pp. 646-648, 2014.

[15] M. A. Miranda, R. F. J. Tiossi, M. R. da Silva et al., "In vitro leishmanicidal and cytotoxic activities of the glycoalkaloids from Solanum lycocarpum (Solanaceae) fruits," Chemistry \& Biodiversity, vol. 10, no. 4, pp. 642-648, 2013.

[16] M. I. Morais, M. E. A. Pinto, S. G. Araújo et al., "Antioxidant and antifungal activities of Smilax campestris Griseb. (Smilacaceae)," Natural Product Research, vol. 28, no. 16, pp. 1275-1279, 2014.

[17] S. G. Araújo, M. E. A. Pinto, N. L. Silva, F. J. L. Santos, A. H. F. Castro, and L. A. R. S. Lima, "Antioxidant and allelopathic activities of extract and fractions from Rosmarinus officinalis," Biochemistry and Biotechnology Reports, vol. 2, no. 1, pp. 35-43, 2013.

[18] S. Burda and W. Oleszek, "Antioxidant and antiradical activities of flavonoids," Journal of Agricultural and Food Chemistry, vol. 49, no. 6, pp. 2774-2779, 2001.

[19] D. J. Finney, Probit Analysis. A Statistical Treatment of the Sigmoid Response Curve, Cambridge University Press, Cambridge, UK, 1980.

[20] P. R. Twentyman and M. Luscombe, "A study of some variables in a tetrazolium dye (MTT) based assay for cell growth and chemosensitivity," British Journal of Cancer, vol. 56, no. 3, pp. 279-285, 1987.

[21] Clinical and Laboratory Standards Institute (CLSI), Methods for Dilution Antimicrobial Susceptibility Tests for Bacteria That Grow Aerobically, Standard M7-A7, Clinical and Laboratory Standards Institute (CLSI), Wayne, Pa, USA, 7th edition, 2006.

[22] A. F. Costa Torres, R. T. Dantas, M. H. Toyama et al., "Antibacterial and antiparasitic effects of Bothrops marajoensis venom and its fractions: phospholipase A 2 and l-amino acid oxidase," Toxicon, vol. 55, no. 4, pp. 795-804, 2010.

[23] M. di Rosa, "Effect of non steroidal anti-inflammatory drugs on leukocyte migration," in Future Trends in Inflammation, G. P. Velo and D. A. Willoughby, Eds., pp. 143-152, Piccin Medical Books, Padova, Italy, 1974.

[24] L. Levy, "Carrageenan paw edema in the mouse," Life Sciences, vol. 8, no. 11, pp. 601-606, 1969.

[25] J. A. Vinson, Y. A. Dabbagh, M. M. Serry, and J. Jang, "Plant flavonoids, especially tea flavonols, are powerful antioxidants using an in vitro oxidation model for heart disease," Journal of Agricultural and Food Chemistry, vol. 43, no. 11, pp. 2800-2802, 1995.

[26] S. A. Wiseman, D. A. Balentine, and B. Frei, "Antioxidants in tea," Critical Reviews in Food Science and Nutrition, vol. 37, no. 8, pp. 705-718, 1997.

[27] H.-C. Huang, K.-Y. Syu, and J.-K. Lin, "Chemical composition of Solanum nigrum linn extract and induction of autophagy by leaf water extract and its major flavonoids in AU565 breast cancer cells," Journal of Agricultural and Food Chemistry, vol. 58, no. 15, pp. 8699-8708, 2010. 
[28] M. T. F. Cornelius, C. C. F. Alves, T. M. S. Silva et al., "Solasonin and flavonoids isolated from Solanum crinitum Lam," Revista Brasileira de Farmácia, vol. 85, no. 2, pp. 57-59, 2004.

[29] A. Bovy, E. Schijlen, and R. D. Hall, "Metabolic engineering of flavonoids in tomato (Solanum lycopersicum): the potential for metabolomics," Metabolomics, vol. 3, no. 3, pp. 399-412, 2007.

[30] M. Gohar, K. Faegri, S. Perchat et al., "The PlcR virulence regulon of Bacillus cereus," PLoS ONE, vol. 3, no. 7, Article ID e2793, 2008.

[31] V. M. Doll, M. Ehling-Schulz, and R. Vogelmann, "Concerted action of sphingomyelinase and non-hemolytic enterotoxin in pathogenic Bacillus cereus," PLoS ONE, vol. 8, no. 4, Article ID e61404, 2013.

[32] M. Al-Fatimi, M. Wurster, G. Schröder, and U. Lindequist, "Antioxidant, antimicrobial and cytotoxic activities of selected medicinal plants from Yemen," Journal of Ethnopharmacology, vol. 111, no. 3, pp. 657-666, 2007.

[33] F. O. Jimoh, A. A. Adedapo, and A. J. Afolayan, "Comparison of the nutritional value and biological activities of the acetone, methanol and water extracts of the leaves of Solanum nigrum and Leonotis leonorus," Food and Chemical Toxicology, vol. 48, no. 3, pp. 964-971, 2010.

[34] P. Bontempo, V. Carafa, R. Grassi et al., "Antioxidant, antimicrobial and anti-proliferative activities of Solanum tuberosum L. var. Vitelotte," Food and Chemical Toxicology, vol. 55, pp. 304312, 2013.

[35] A. Burke, E. M. Smyth, and G. A. FitzGerald, "Analgesic, antipyretic and anti-inflammatory agents: pharmacotherapy of gout," in The Pharmacological Basis of Therapeutics, A. G. Gilman, L. S. Goodman, and A. Gilman, Eds., pp. 671-715, McGraw-Hill, New York, NY, USA, 11th edition, 2006.

[36] S. Khan, M. H. Mehmood, A. N. A. Ali, F. S. Ahmed, A. Dar, and A.-H. Gilani, "Studies on anti-inflammatory and analgesic activities of betel nut in rodents," Journal of Ethnopharmacology, vol. 135, no. 3, pp. 654-661, 2011.

[37] N. Loganayaki, P. Siddhuraju, and S. Manian, "Antioxidant, anti-inflammatory and anti-nociceptive effects of Ammannia baccifera L. (Lythracceae), a folklore medicinal plant," Journal of Ethnopharmacology, vol. 140, no. 2, pp. 230-233, 2012.

[38] E. M. Conner and M. B. Grisham, "Inflammation, free radicals and antioxidants," Nutrition, vol. 12, no. 4, pp. 274-277, 1996.

[39] F. Yang, W. J. S. de Villiers, C. J. McClain, and G. W. Varilek, "Green tea polyphenols block endotoxin-induced tumor necrosis factor-production and lethality in a murine model," Journal of Nutrition, vol. 128, no. 12, pp. 2334-2340, 1998.

[40] M. H. Pan, S. Y. Lin-Shiau, C. T. Ho, J. H. Lin, and J. K. Lin, "Suppression of lipopolysaccharide-induced nuclear factorkappaB activity by theaflavin-3,3'-digallate from black tea and other polyphenols through down-regulation of IkappaB kinase activity in macrophages," Biochemical Pharmacology, vol. 59, no. 4, pp. 357-367, 2000.

[41] D. Ichikawa, A. Matsui, M. Imai, Y. Sonoda, and T. Kasahara, "Effect of various catechins on the IL-12p40 production by murine peritoneal macrophages and a macrophage cell line, J774.1," Biological and Pharmaceutical Bulletin, vol. 27, no. 9, pp. 1353-1358, 2004. 


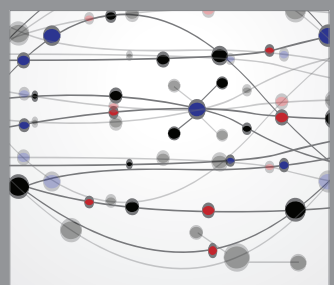

The Scientific World Journal
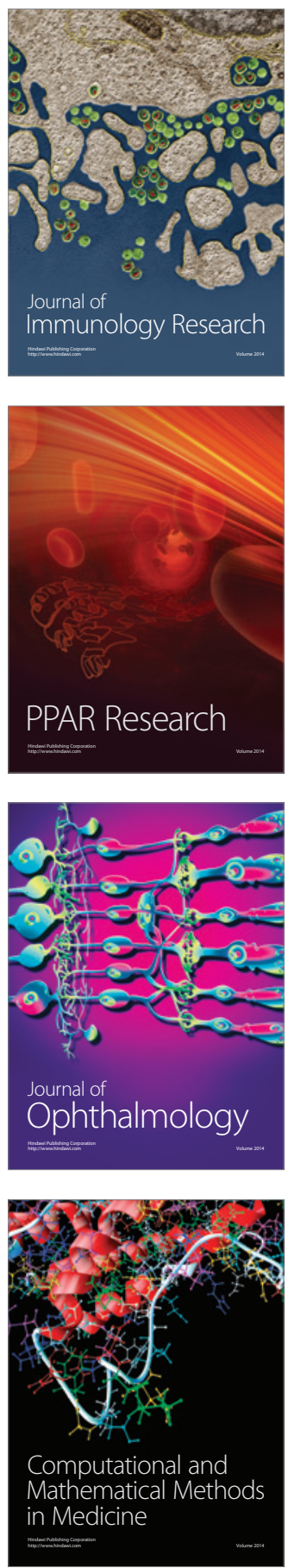

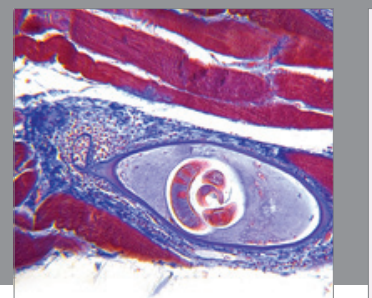

Gastroenterology

Research and Practice
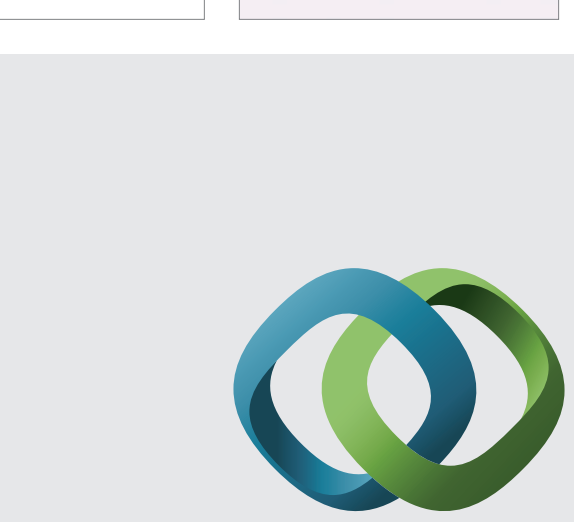

\section{Hindawi}

Submit your manuscripts at

http://www.hindawi.com
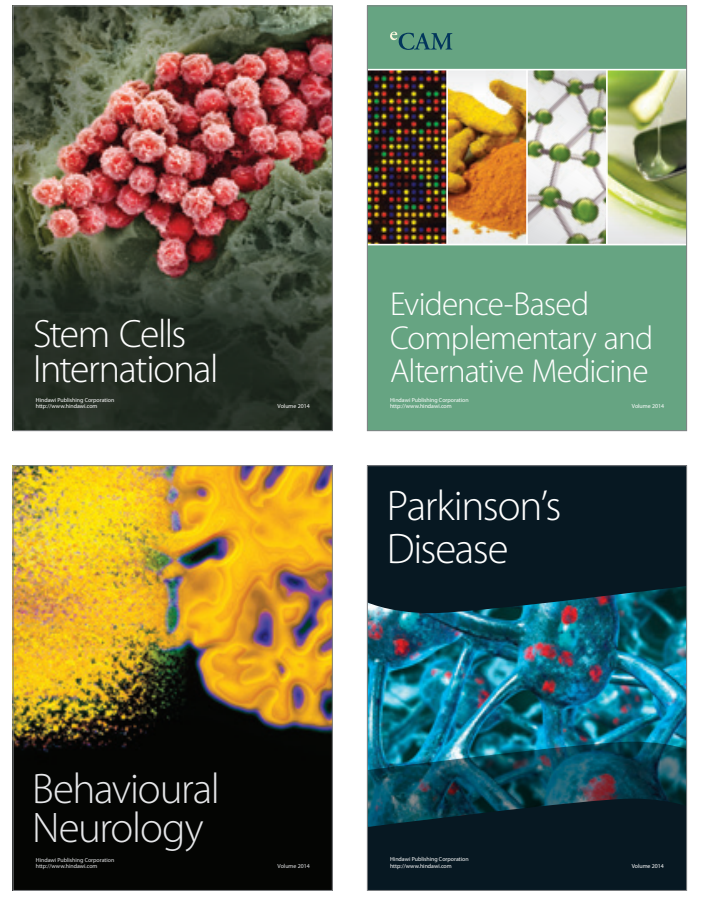
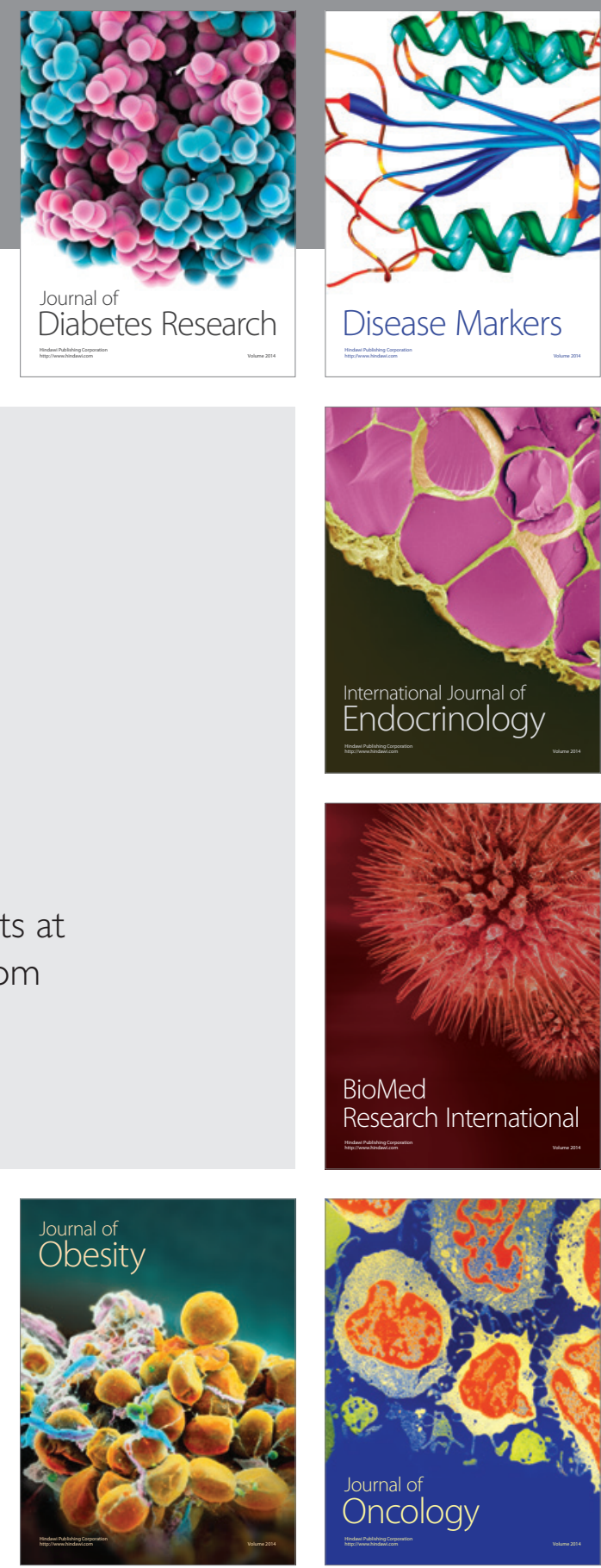

Disease Markers
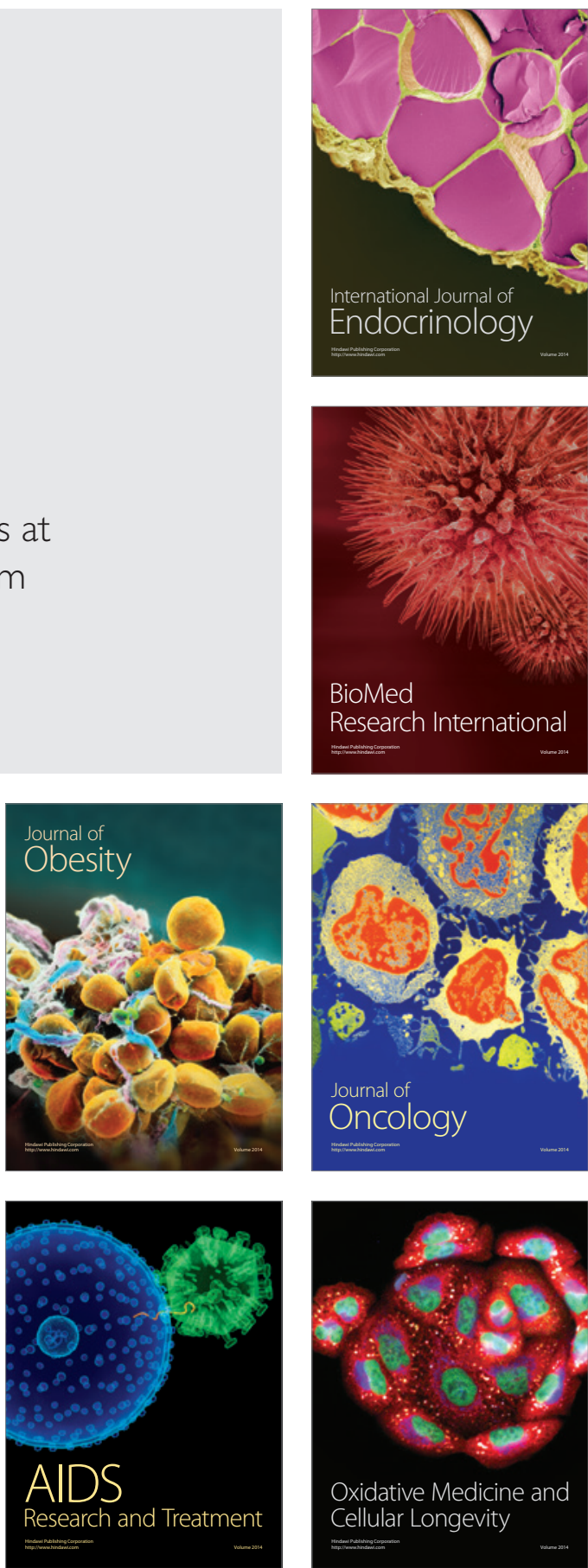